\title{
Anthropology in Colombia and the Dynamics of the Labor Market
}

\author{
Jorge Alberto López-Guzmán* \\ Anthropologist, Politologist, Universidad del Cauca, Colombia
}

Submission: April 02, 2019; Published: April 18, 2019

*Corresponding author: Jorge Alberto López-Guzmán, Anthropologist, Politologist, Specialist and Magister in Government and Public Policies. Universidad del Cauca, Colombia

\begin{abstract}
This article succinctly exposes the history of anthropology in Colombia, emphasizing its relationship with different socio-political conjunctures, and culminates establishing the relationship of what to do about anthropology and the role of anthropologists with current needs and labor market demands in the country.
\end{abstract}

Keywords: Anthropology in Colombia; State; Market

\section{Introduction}

Restrepo, Rojas \& Saade [1], state that the anthropology that has been done in Colombia, by residents, non-residents, Colombians and foreigners in relation to the themes, methodologies and policies have been influenced by the State and the institutional transformations, which demonstrates an important place in the discipline and its professional practice in the areas of opinion, decision-making and performance activities, allowing to relate the training of anthropologists in the country and its contribution to the understanding of government problems, conflicts -environmental, economic development, armed conflict, among other issues. In this regard, García Botero [2], states that Colombian anthropology has enabled the effective transformation of the understanding of the world, to question the inheritance of a thought that was organized around the political asymmetries that were familiar.

The discipline in the country has been strengthened since its inception with the subject / study subject the indigenous who lived in the jungles, plains and mountains, mainly in areas of the Amazon, Eastern Plains, the Sierra Nevada, the department of Cauca [3]; and when research was carried out in urban anthropology or with non-indigenous groups, little was taken into account in the last century, even more so when they distanced themselves methodologically from the participant observation and the stay in a specific place during a specific time.

However, at present it is no longer only the Indian or indigenous communities that provide information or research to anthropologists. The professional is being called to fields previously not considered, mainly in a country like Colombia where the cultural and biological diversity have been conjugated in many occasions with political and war contexts. Entities are demanding the functions of anthropologists to develop activities with rural communities, minorities ethnic, or in fields such as business, humanitarian or vulnerable, or oil companies and mining companies, often hire them to manage intercultural relations and implement mitigation plans for socio-cultural and socio-environmental impacts within the territories [4].

Between the Milestones of the Anthropological Quehacer and the Anthropologists 'Office

The exercise of anthropology in Colombia and in general in Latin America, has been linked by a strong political condition to the construction of nation-states, unlike anthropology in the European context, where the discipline was configured from a colonial perspective in knowledge function of the southern hemisphere (Africa, Oceania and America). It is also the case of the American anthropology that has stood out for having numerous departments of anthropology, as well as museums, foundations and other institutions related to the discipline; the anthropologists who have been trained in that country mostly have as their objects of study external societies or that at some point belonged to the colonial sphere [5]. While European and American anthropology were part of a colonialist process, Latin American countries contributed to the project of modernization of the States, using the western model and indigenist policies [6]. That is, Colombian anthropology belongs to the genre of peripheral or southern anthropologies [5] where anthropologists have stood out for their contribution to the construction of national projects, or at least for certain projects, and have contributed to the creation of the great myths 
or metanarratives of the nation. As Jimeno [7] Latin American anthropology has left behind the indigenismo and faces new conjunctures. Nonetheless, it continues to look for mirrors of otherness and sameness in the face of nation-building, since there are still conflicting projects about what nation-building, democracy and citizenship mean.

In this sense, Arocha \& Friedemann [8] state that the milestones of the discipline and the anthropological office in Colombia are: the expedition of the Corograph Commission (19th century), the Normal Superior School (1936) and the National Ethnological Institute - IEN (1941); The work of the latter was so important that in the second half of the 1940s, subsidiaries were created in Antioquia, Cauca, Atlántico, Boyacá and Magdalena, some of which were devoted to archaeological and ethnohistorical research. Other references of anthropology are: the Colombian Institute of Anthropology (1952) and the creation of the first four departments at the university level, the University of the Andes (1964), the National University (1966), the University of Antioquia (1966) and the Universidad del Cauca (1970). Within the background of anthropology as a discipline, there is also the founding of the National Archaeological Service by Gregorio Hernández de Alba as part of the Section of Cultural Extension and Fine Arts of the Ministry of National Education, which aimed to establish of a large-scale social research program in Tierradentro, through archaeological research and applied anthropology, this being the first institutional anthropologyarcheology work carried out in the department of Cauca [9].

In the same way, a relevant reference in the training of the first anthropologists in Colombia was the Frenchman Paul Rivet within the IEN, who wanted the future ethnologists to be trained in teaching activities and periodic investigations in the field, based on Americanism, functionalism of Malinowski, Durkheim and Mauss, and the particularism of Boas. The training included short expeditions for the collection of basic information and objects of indigenous peoples [1]. In this context, Dussán de Reichel affirms that in the beginnings of anthropology as a discipline in Colombia and specifically in the department of Cauca with the Ethnological Institute of Cauca IEC, the first technicians and professionals in different fields of ethnology can be glimpsed. social anthropology, focusing on the study of indigenous communities, which sought to study processes of acculturation and disappearance of indigenous communities, so it was necessary to study them before their practices and traditions ceased to exist. Similarly, in the city of Popayán, studies were sponsored on black communities, Gregorio Hernández de Alba himself would write an interesting work on the history of manumission; In addition, at the Instituto del Cauca received courses Rogerio Velásquez and Aquiles Escalante, along with the Jesuit Father Rafael Arboleda, pioneers of African-American studies in our country [10].

Therefore, from the IEC, the Unicauca Anthropology program was created, with the objectives of teaching physical anthropology, archeology, American and Colombian ethnology, and linguistics. Subsequently, the work of the Institute of Anthropology of Unicauca in the decade of the sixties and seventies, focused on providing analysis for social research from teaching and research in local and departmental areas [11]. By the end of the sixties and until the first half of the seventies, with the emergence of anthropology programs in universities, the first generation of students trained in anthropology in the different universities began to be titled, consolidating three aspects regarding the work of the discipline and the role of the professional; At first, the solidarity struggle with the natives was born, leaving them to see as objects of study and valuing their knowledge, authority and territory; part of this influence was given thanks to the reflections given in the First Declaration of Barbados (1971); in a second moment, there is the militant perspective in vogue to support the marginalized sectors that suffered from exploitation by concrete social and political practices; and in the third moment, an anthropology compromised with the construction of citizenship is glimpsed [1].

At the end of the sixties and the beginning of the seventies there was a boom in peasant movements and organizations, among them the first indigenous organization of protest character was created in Cauca (Regional Indigenous Council of Cauca - CRIC, 1972), as a result of the active presence of the natives that had a remarkable influence on the rethinking of the young anthropologists, since the Indian was no longer seen as an object of study, and he was conceived as an active subject that influenced his own history and that of his territory. In this context, the relation between the legal and the cultural is born from the struggles of the ethnic groups that fought against the repression of the State, which suddenly occupied the offices of the judges with judging processes to people coming from diverse cultures mainly due to issues of recovery or invasion of lands, homicide of landowners and / or settlers. Already in the eighties stands out a boom of urban anthropology in Colombia, these works largely had to do with the development of theses that were made in institutions of the State, the topics worked referred to case studies related to vulnerable sectors of the cities, schooling, demography, among others. In addition, within the urban culture of the eighties, aspects such as demographic growth, the process of industrialization, the displacements from rural to urban, subcultures within the city were combined, all this configuring regional identities that were and still are studied by anthropologists [12].

By the end of the eighties, the discussion of the task and the role was related to the political-administrative decentralization that the Colombian State was going through. In this regard, the $\mathrm{V}$ National Congress of Anthropology in Colombia (1989), held in Villa De Leyva, analyzed the implications of the decentralization process and the limitations of the professional practice of anthropology in relation to administrative change. When the memoirs of the congress are analyzed, there are researches like those of the anthropologist Hernán Henao, a professor at 
the University of Antioquia, about Cultural Research in Local and Regional Contexts where it is exposed that Colombian anthropology is not only a discipline that prioritizes the indigenous communities for their study, but also the mestizo contexts, where anthropology affects the planning processes of the communities and the State.

In addition, researchers like Roberto Pineda Camacho, Gabriel Restrepo Forero, Orlando Pulido Chaves, Eduardo Barraza and Carlos Vladimir Zambrano, expose within the memoirs of the $\mathrm{V}$ Congress a discussion of political anthropology on the role of anthropologists in the nineties, in It seeks to diversify the referents and the traditional study places of anthropology until that moment, manifesting processes of interculturality, geographical differentiation and the inclusion of mestizo peoples within the concerns of professionals. Consequently, variables such as language, religion, and law become references for thinking anthropology from the academic and the political; At a time when the country was discussing the indigenous people, their rights and the black culture, the discussion of diversity at its highest level for Colombian anthropology that was entering a change of Political Constitution and economic model was envisioned.

At the beginning of the 21st century, the Ninth Congress of Anthropology in Colombia (2000) was held in Unicauca. The congress had among its symposia, panels and forums, novel subjects that the anthropological discipline began to work incipiently like the anthropology of war, a topic historically treated in Colombia by disciplines such as history, political science and sociology. Similarly, the theme of archeology, heritage and the relationship with the State, as well as topics such as the anthropology of religion, Afro-Colombian ethnicity and social movements. In short, the different stages of anthropology in Colombia have been marked by a constant relationship with the political conjunctures, the difference between the subject and the object, that is between the researcher and the researched, defining the nature of the profession and the vocation. Thus, since the year 2000 anthropology as a discipline has undergone changes of institutional order from the incidence of the State in the regulation of anthropology programs in universities.

Currently, anthropologists are being called to exercise their knowledge around global processes such as working in mining and oil companies, granting new concepts to field work and to the task of the discipline, configuring a new relationship between the researcher and the field work, mainly in consultancy work, where "fast ethnographies" of fulfillment of activities for delivery of products are established, losing or constructing new symbolic dynamics in territories where social and ethical commitment is almost nil, leading to some programs are training students with the ability to be technicians in anthropology, even when the degree is undergraduate or bachelor's degree in anthropology [13]. Anthropologists are linking up thanks to market demands, in matters of corporate social responsibility, prior consultation and ethnography of consumption, pointing their research and activities to the perceptions and behaviors of consumers, in economic and infrastructure projects [1].

In this sense, anthropology ends up correlating with the results that the market and the States need or impose, and this is where universities and training centers must rethink the training and curricula they offer, since currently educational policies have been designed to train workers according to the needs imposed by international policies, rather than the training of critical subjects that transform the problems of the environment.

\section{Women and the Anthropological Discipline in Co- lombia}

Within the framework of modernization by the liberal governments, the strategies of renovation and strengthening of education in the country were given, and the recovery of the indigenous legacy as a basis of the colonial past. This is how the Higher Normal School was established in 1936, which taught subjects such as linguistics, social sciences, biological sciences and mathematics. Its director José Francisco Socarrás, had the initiative to promote the inclusion of women in a controversial and innovative coeducation project [14], whose background was the mobilizations of women in the first three decades of the twentieth century, who received support from then President Enrique Olaya Herrera (1930-1934) who arranged for the transition of women to secondary and university education [15], the decade of the 1930s being a labor scenario of equal participation between men and women, legitimizing access to new jobs in the professional world.

As part of the educational reform project with the Normal Superior, the IEN was created where the pioneering women of anthropology in Colombia made their professional studies: Alicia Dussán, Virginia Gutiérrez, Edith Jiménez and Blanca Ochoa, who also became involved in higher education as founders of the practice and professionalization of anthropology [16] where they carried out different research, publications and dissemination projects between 1941 and 1949, when the institute became the ICAN. In the words of Luis Duque Gómez: The field of social anthropology is very sensitive for women and it was not so risky for a woman to study anthropology, which was to study the Indians, and the Indians were handled by the missionaries (...). Saying 'I'm going to face a high-surgical operation or defend a defendant in a courtroom trial, or face a train or a lane', not that! (...) I think that the woman felt a little closer to this field thinking of the Indians, or in the study of the past of the Indians, a little with the spirit of a missionary (Interview with Luis Duque Gómez, October 17, 1996 quoted in Echeverri, 2007).

Consequently, the contribution of the first Colombian anthropologists, trained in the Escuela Normal Superior and the IEN, was fundamental within anthropology as a discipline and institutionalized in Colombian universities, as the anthropologist Reichel Dolmatoff stated about his wife Alicia de Dussán; he highlighted her as an exceptional field worker, in her work she practiced all areas of anthropology, innovated in methods and 


\section{Global Journal of Archaeology \& Anthropology}

techniques of studies, both archaeological and ethnographic [17]. In this context, Bernal [18] raises some characteristics of the anthropological studies of the time:

a. They reveal ethnocentrism in the social sciences and reassess the perspectives that were presented by purely descriptive studies or with pretended neutrality.

b. They denounce situations of oppression and marginality and act accordingly to transform them.

c. Analyze different human groups as part of the same structure and not as isolated communities.

Despite their academic recognition, the first anthropologists found it difficult to enter masculine spaces. Nonetheless, they helped to foster interest in the study of domestic spheres, in addition, they contributed to the approach in the field, to subjects regularly minimized in the anthropological research of the moment, children and women were their closest collaborators in their research [18]. In short, anthropologists have historically been conceived as better interlocutors for their inborn attributes of mothers or daughters, which has allowed them to forge greater trust with communities, excluded sectors, discriminated against or minority. As Echeverri [16] puts it, in the first ethnological investigations women had a great place, since they were perceived as educators naturally, and in many cases, they were linked to the representation of the missionary world, from their affinities of equality and protection. Additionally, the anthropologists showed with their professional option, a proposal to be women investigators, implying with it a different role to that of daughter, sister or wife and participating in a disciplinary and professional field, different from the feminized professionals of the time [18].

\section{Anthropology and Market}

For several years the need of the labor market has been perceived for hiring professionals in social and human sciences, mainly by NGOs and bureaucratic requirements of the State, both sectors demand knowledge to advance social intervention work, the design of policies public and the resolution of socio-cultural conflicts. The most worrisome is that they stipulate in their calls that these works should be done in a matter of months, causing prolonged field work, as it had been conceived by classical anthropology, disappears in favor of rapid dives and compliance with contractual activities [19]. That is, neoliberalism has coopted the essence of the social and human sciences, to the point of bureaucratizing them, and professionals are governed by activities that do not generate greater impact in the communities where they intervene. Therefore, we must advocate for the training of freethinking and critical professionals, who from their jobs, whether they are providing services, are not marginalized from their management skills and social transformation. In the words of Mexican ethnoecologist Víctor M Toledo [20].

Twentieth century scientific research gradually went to the service of war and corporations. The process of deployment and maturation of the scientific apparatus of the countries was becoming a process of commodification of knowledge. Corporate capital in all its branches not only generated science for its interests, but it was co-opting the research of public universities and government offices by financing multiple projects. In the United States, for example, corporate funding for science and innovation went from less than 40 percent to 65 percent between 1965 and 2006. The idealized image of a science at the service of humanity, which Certain is the dogma that frames most of the so-called scientific dissemination, it was becoming just that: a fiction fueled by the false idea that there is only one science, which is morally good and ideologically and politically neutral. Today, in only the 10 largest weapons manufacturing companies, about 100 thousand scientists and engineers use their knowledge and skills for destruction. In contrast to the industrialized countries, where science effectively performs its role in the service of capital, in the countries in the process of being so, islands or bubbles of science remain at the service of their societies (in their public universities and technology). However, as corporate capital expands and increases its influence, these bastions of independent scientific thought are falling one by one and technoscience ends up irremediably dominating.

Some professionals are required in offices as part of the bureaucratic structure, while others are used in field work to collect information or to relate to communities [4]. Often, oil companies or mining companies count among their employees with anthropologists in charge of establishing and managing relations with local populations and carrying out prior consultation processes. In the same way, the armed conflict has been a niche for the work of anthropologists hired by the State or by NGOs, as it has been exposed previously, it is the professional field where the task of the discipline is most required. By 1980, the social and human disciplines were in a period of crisis: crisis of concepts, crisis of methods, and deeply, crisis of legitimacy. Indeed, some academics began to deny all scientific authority in the works of the anthropologists who had preceded them, as well as to the works produced before they had become aware of the fictional and ideological nature of the narratives constructed by Western anthropologists, to give to know what they intended to have understood about nature, other forms of culture and society [21].

Although, Immanuel Wallerstein in the book Open Social Sciences (2004), states that social science is a business of the modern world that began to develop since the sixteenth century, which aims to develop a systematic secular knowledge about the reality that have some type of empirical validation, which caused the annoyance and antagonistic position of those who conceived as a unique science, the natural and exact sciences. However, by the eighteenth-century different thinkers began to recognize the existence of multiple types of social systems in the world, whose diversity required explanations that only the hegemonic sciences came close to giving. 
It is in this context, when the university takes a position away from the church and during the eighteenth and nineteenth centuries becomes the main headquarters of knowledge creation from different perspectives, the faculty of theology lost relevance, while the medical school preserved his role, and it was within the faculty of philosophy and law where modern knowledge structures were built. The universities became the main headquarters of the continuing tension between the arts or humanities and the natural and exact sciences, which began to be defined as antagonistic modes of knowledge. In this sense, the social sciences were formally recognized in the main universities, in the forms that are currently known, in the period between 1850 and 1914. Thus, for the First World War, five disciplines were consolidated and institutionalized: history, economics, sociology, political science and anthropology; without ignoring the institutionalization of psychology and law. By 1945, the disciplines that make up the social sciences were basically institutionalized in most major universities around the world. However, considering that the discipline of interest is anthropology, it is proposed that: Some of the early anthropologists were interested in the natural history of humanity (and its presumed stages of development) [...] pressures from the outside world prompted anthropologists to become particular ethnographers of particular peoples. Inevitably, it implied a concrete methodology, built around field work (which met the requirement of empirical research of scientific ethics) and participant observation in a particular area (fulfilling the requirement to achieve an in-depth knowledge of the culture needed to his understanding, so difficult to achieve in the case of such a strange culture for the scientist). Participant observation always threatened to violate the ideal of scientific neutrality, as well as the ever present temptation for the anthropologist (as well as for the missionaries) to become a mediator between the studied people and the conquered European world, particularly because the anthropologist used to to be a citizen of the colonizing power of the people under study [22].

In the case of Colombia, the social sciences were shaped by different socio-political conjunctures that fostered intense debates about the nature of national identity, social memory and historical thought, building school practices, curricula and pedagogies, and above all the customs, habits and citizen actions. According to Serna [23], in the course of the twentieth century can be located four junctures specially to encourage debates in the social sciences. The first conjuncture, provoked by the war of the Thousand Days and the Panamanian secession, brought the establishment of the Colombian Academy of History and with it, a canonical vision of history as luck of civic religion watched over by the State. The second conjuncture, in the middle of the 20th century, in the midst of partisan violence, brought the first points between a canonical vision of history and a historical thought more open to modern social sciences. The third conjuncture, between the seventies and eighties, in the middle of the intensification of the armed conflict, between the insurgencies (guerrillas and paramilitaries) and the public forces, generate that social sciences have a critical and convinced vision with social emancipation. Finally, by the end of the 20th century and the beginning of the 21st with the new constitutional regime, the aim is to contain the armed conflict, recognize cultural diversity and innovate economically.

In the course of these conjunctures, the debate on the teaching of the social sciences, the historical thought and the school was exposed to a quite problematic delimitation imposed to a large extent by the predominance of the disciplinary eyes with its capacity to shield areas of knowledge - On one side were located issues related specifically to the cognitive, pedagogical and didactic dimensions of historical thought in the teaching of social sciences, which, considered as privileged domains of psychopedagogy, psychology, pedagogy and didactics, should be the fundamental concern of teachers in their daily work; On the other hand, the issues related specifically to the social, cultural and political dimensions of historical thought in the teaching of social sciences were located, which, considered as privileged domains of history, sociology and anthropology, were issues that went beyond the scope of teachers' competence [23].

In this context, the social and human sciences in schools and colleges have been conceived as institutions capable of uniting citizens in search of a national identity, trying to understand and try to solve the socio-political problems that have arisen historically in the country, that is, through narrating events with a strong moral charge, and in many cases depending on political interests. These stories that are addressed, have as protagonists a ruling class that has given the course to the homeland, and also highlights a set of villains that have been and are the problem of the country, in addition to the invisibility and stigmatization of communities original. This is how the teaching of social and human sciences in Colombia was built preserving traditions and customs of the elites, the recognition of national heroes, military deeds, patriotic ideals, habits of discipline, order and respect for the authorities and national iconography. However, it should not be ignored that within the Liberal Reforms (1930-1946) the classes of social and human sciences suffer an inflection and take a critical tinge on the past; although this happened, the political interest persisted [24].

With Law 115 of 1994, which regulated the general norms that stipulate the public service of education in the country, increased confusion about the contents of the social and human sciences that should be taught in schools and colleges, was declared as obligatory areas in basic education: Social Sciences, History, Geography, Political Constitution and Democracy. Subsequently, between 2002 and 2004, the MEN began to reform the Curricular Guidelines of Social Sciences; The problem with these guidelines is that they produced a return to traditional, repetitive, memorial teaching, based on new titles, sections and contents [24]. In addition, curricular guidelines were issued in 
the country for areas close to the social sciences, with issues raised by the situation of violence and the timing of the issuance of the 1991 Constitution: Education, Ethics and Human Values, and Political Constitution and Democracy, subjects of legitimate interest but that reflect two disturbing symptoms: first, that the gaps left by an unintegrated teaching of the social sciences were replaced by remedial materials, sometimes conceived as solutions to emergencies, or according to preferences of the rulers (as happened with the Bolivarian Chair, Afro-Colombian, the perspective of Gender or Human Rights); and, second, that a rhetoric was imposed on ethics, citizenship and democracy that came to formally overlap with the teaching of social sciences [24].

The relevance and importance of the social and human sciences as disciplines not only in schools and colleges, but as professions to understand the problems, situations, histories and contexts of Colombia, are fundamental, since they allow knowing, recognizing, criticizing or claiming the past, the cultural and biological diversity, understand and explain the genealogies of the different actors and conflicts that have been generated and that could be generated, and know the territories and particularities of these. In this way, it is how social and human disciplines become essential to understand the divergences and convergences that are generated in Colombia, where anthropological studies have been and continue to be strategic for the construction of a national identity, knowledge of cultures and peoples, of knowledge and practices. Anthropologists have become interlocutors for the resolution or transformation of social, political and economic problems. Currently, the profession of the anthropologist and social scientists is necessary in all areas of government, whether for the design, implementation or evaluation of rural and urban plans, programs or projects, with women, children and communities. local, new subjects of rights, even with the same biodiversity.

\section{References}

1. Restrepo E, Rojas A, Saade M (2017) Anthropology made in Colombia. Universidad del Cauca, Colombia.

2. García Botero H (2008) Anthropology of anthropology: Questioning alterity: reflections on the historiography of Colombian anthropology. In: Maguaré. No. 22, Bogotá, Colombia, 22: 455-481.

3. Restrepo E, Uribe MV (1997) Anthropology in Modernity. Colombian Institute of Anthropology, Colombia.

4. Restrepo E (2014) Anthropology Made in Colombia. Anthropologies Magazine of the South. pp. 83-104.

5. Pineda Camacho R (2007) Colombian anthropology from a Latin American perspective. In: Colombian Journal of Anthropology. No. 43, Bogotá, Colombia, 43: 367-385.
6. Pérez AL (2010) Peripheral anthropologies. A look at the construction of anthropology in Colombia. In: Bulletin of Anthropology Universidad de Antioquia 24(41): 399-430.

7. Jimeno M (2004) The critical vocation of anthropology in Latin America. In: Maguaré. No. 18, Bogotá, Colombia, 18: 33-58.

8. Arocha J, Friedemann de N (1984) A century of social research. Anthropology in Colombia. Editorial Etno, Bogotá, Colombia.

9. Tabares RE, Meneses LE (2016) History of anthropology in Cauca. 40 years of anthropological exercise through undergraduate monographs. Universidad del Cauca, Colombia.

10. Pineda Camacho R (2004) The school of Colombian anthropology. Notes on the teaching of anthropology. Maguaré, Colombia, 18: 59-85.

11. Méndez M (1967) Anthropology in Colombia. University of Cauca, Popayán, Colombia.

12. Muñoz J (1990) Colombian cultural anthropology. Ministry of National Education, Bogotá, Colombia.

13. Ramírez S (2017) Field work in contemporary anthropology: merchandise and globalization in Latin America. In: Tocancipá-Falla (Eds.), Anthropologies in Latin America. Universidad del Cauca, Colombia.

14. Pineda Giraldo R (2000) Anthropology in Colombia. In Discourse and reason. A history of the social sciences in Colombia, edited by Francisco Leal Buitrago and Germán Rey. Ediciones Uniandes- Fundación Social-Tercer Mundo Editores, Bogotá, Colombia.

15. Cohen L (2001) Colombians in the forefront. University of Antioquia, Medellín, Colombia.

16. Echeverri M (2007) Pioneering Anthropologists and Liberal Nationalism in Colombia, 1941-1949. Colombia Magazine of Anthropology, Colombia, 43: 61-90.

17. Pineda Camacho R (2012) The Adventure of being an Anthropologist in Colombia: Alicia Dussán de Reichel-Dolmatoff and Social Anthropology in Colombia. Maguaré Magazine, Colombia, 26(1): 15-40.

18. Bernal E (2013) Women students of anthropology in the 1970s. Field notes in the study about their construction of anthropological land. Colombia: In: Maguaré 27(2): 259-284.

19. Godoy Ferro M (2017) Do not count on our astuteness: neoliberal logics in Colombian anthropology. Universitas Humanística, 84: 309-325.

20. Toledo V (2016) Science, ethics and ecology the Journey, Mexico.

21. Godelier M (2016) In today's world, anthropology is more important than ever AIBR. Revista de Antropología Iberoamericana, 11(1): 59-77.

22. Wallerstein I (2004) Open Social Sciences. Siglo XXI (Eds.), Mexico.

23. Serna A (2015) Social sciences, historical thought and citizenship: between the allegorical and virtual (Colombia, 1910-2010). Bogotá: Universidad de los Andes - Social Studies Magazine 52: 147-157.

24. Arias D (2015) The teaching of the social sciences in Colombia: place of the disciplines and dispute for the hegemony of a knowledge. Universidad de los Andes, Bogotá, Colombia, Journal of Social Studies 52: 134-146. 
(C) This work is licensed under Creative

DOI: 10.19080/GJAA.2019.08.555748

\section{Your next submission with Juniper Publishers} will reach you the below assets

- Quality Editorial service

- Swift Peer Review

- Reprints availability

- E-prints Service

- Manuscript Podcast for convenient understanding

- Global attainment for your research

- Manuscript accessibility in different formats

( Pdf, E-pub, Full Text, Audio)

- Unceasing customer service

Track the below URL for one-step submission https://juniperpublishers.com/online-submission.php 